\title{
Learning and Teaching Interdisciplinary Skills in Sustainable Urban Development-The Case of Tampere University, Finland
}

\author{
Jonathon Taylor ${ }^{1, *,+}+$, Salla Jokela ${ }^{2,+}$, , Markus Laine ${ }^{3,+}$, Juho Rajaniemi ${ }^{1}$, Pekka Jokinen ${ }^{3}$, Liisa Häikiö ${ }^{2}$ and \\ Antti Lönnqvist ${ }^{1}$ \\ 1 Faculty of Built Environment, Tampere University, 33720 Tampere, Finland; juho.rajaniemi@tuni.fi (J.R.); \\ antti.lonnqvist@tuni.fi (A.L.) \\ 2 Faculty of Social Sciences, Tampere University, 33014 Tampere, Finland; salla.e.jokela@tuni.fi (S.J.); \\ liisa.haikio@tuni.fi (L.H.) \\ 3 Faculty of Management and Business, Tampere University, 33100 Tampere, Finland; \\ markus.laine@tuni.fi (M.L.); pekka.jokinen@tuni.fi (P.J.) \\ * Correspondence: jonathon.taylor@tuni.fi \\ + J.T., S.J., and M.L. contributed equally to this work as joint first authors.
}

Citation: Taylor, J.; Jokela, S.; Laine, M.; Rajaniemi, J.; Jokinen, P.; Häikiö, L.; Lönnqvist, A. Learning and Teaching Interdisciplinary Skills in Sustainable Urban Development-The Case of Tampere University, Finland. Sustainability 2021, 13, 1180. https:// doi. org/10.3390/su13031180

Academic Editor: Manuel

Duarte Pinheiro

Received: 22 December 2020

Accepted: 21 January 2021

Published: 23 January 2021

Publisher's Note: MDPI stays neutral with regard to jurisdictional claims in published maps and institutional affiliations.

Copyright: (C) 2021 by the authors Licensee MDPI, Basel, Switzerland. This article is an open access article distributed under the terms and conditions of the Creative Commons Attribution (CC BY) license (https:/ / creativecommons.org/licenses/by/ $4.0 /)$.

\begin{abstract}
Developing the economic, environmental, and social sustainability of urban environments is challenging due to the complex and interconnected nature of the context and objectives. In order to be successful in this challenging environment, professionals working in the urban development arena should have a holistic understanding of the different pillars of sustainable development, as well as various competencies and skills. This paper looks at sustainable urban development (SUD) from the perspective of the skills and competencies required and identifies effective pedagogic practices that could help educate future professionals. In particular, we explore interdisciplinary and transdisciplinary learning, reflective thinking, and experiential learning, which are needed for understanding various aspects of a complex phenomenon, collaborating with professionals from different fields and coming up with novel and constructive ways of solving complex problems. We first examine these through reviewing and analyzing relevant literature on education for sustainable development, with a focus on SUD. Then, we explore the application of these approaches in practice by describing and analyzing a newly introduced degree program at Tampere University, Finland.
\end{abstract}

Keywords: education for sustainable development; pedagogy; urban; multidisciplinary learning

\section{Introduction}

There is an urgent requirement to improve global environmental sustainability, including addressing critical challenges such as reducing greenhouse gas (GHG) emissions, water consumption, biodiversity loss, and accelerating land and resource use [1]. In parallel, a number of interrelated or unique social sustainability challenges need to be addressed, including inequity, social cohesion, inclusion, and justice [2]. These challenges must be faced within the economic and administrative constraints, resulting in social learning and new forms of social-ecological reflectivity and sustainability governance [3,4].

Urban areas are a natural focus for efforts to improve sustainability. They account for an increasing majority (54\%) of the global population [5] and Gross Domestic Product (GDP) (85\%); have a disproportionate share of global energy (60-80\%) and resource consumption (75\%); produce around $50 \%$ of global waste; and emit around $70 \%$ of global GHG emissions [6]. Urban development-defined here as the improvement or expansion of urban physical, social, administrative, and economic infrastructure-needs to be done in a sustainable manner in order to help avoid lock-in of unsustainable urban systems. There are also significant opportunities for sustainable urban development policies to provide co-benefits for population health and wellbeing [7-9]. However, to-date, very few cities have had success in meeting either local or global sustainability challenges (e.g., [10]). 
Urban areas are highly complex systems, with feedbacks, interdependencies, and non-linear linkages between environmental, social, economic, and governance elements of the urban system. This complexity can lead to so-called wicked problems in planning and policy that are extremely difficult if not impossible to solve. Addressing complex societal challenges, such as those targeted for improvement in the Sustainable Development Goals (SDGs), cannot be achieved within narrow disciplinary silos, but require a shift in development practice, and technological, social, and administrative solutions and innovations. Hence, there is a growing need for integrated skills and knowledge to address the key challenges of the Anthropocene [11]. Transdisciplinarity as a practice processes complex, real-life problems by means of methodological cooperation between disciplines, and between researchers and practical actors, and thus enables integrated learning between the scientific community and society $[12,13]$.

Education for Sustainable Development (ESD) has a critical role in providing transdisciplinary skills, with universities having an important role as drivers of sustainable change. However, in education, transdisciplinary teaching of Sustainable Urban Development (SUD) has not seen significant adoption into the established curricula so far [14] and there is limited experience on how to develop and facilitate transdisciplinary teaching of SUD in practice. Therefore, the aims of this paper are to:

(1) Identify the knowledge and skills required for future SUD professionals;

(2) Evaluate current pedagogical practices and limitations of sustainability teaching at the Higher Education Institution (HEI)—level; and

(3) Illustrate and critically reflect on the practical implementation of SUD education at the bachelor's degree level.

To achieve the first two aims, we review and summarize current literature in ESD and analyze how SUD education has been implemented in HEIs worldwide. To achieve the third, we describe as a case study the development of a new bachelor's degree program in SUD at Tampere University, Finland, which aims to equip future sustainable urban development technology, social, and administrative professionals with the skills and holistic understanding to enact sustainable change in a global context. Finally, we reflect on the degree program, illustrating how learning outcomes and pedagogical practices identified in the literature review are integrated into the curriculum, as well as exploring the perspectives of students and practical experiences of lecturers following the programs first implementation.

\section{Methodological Approach}

Our paper includes both a literature review and case study. Existing research into ESD and SUD education has explored the challenges and best practices for educating students about sustainability whilst providing them with the core competencies to be agents of sustainable change. However, the extant literature on the topic can be characterized as fragmented and it is not easy to form a coherent and comprehensive view of key issues related to ESD, particularly in the context of SUD education. Therefore, in order to frame current thinking in ESD, a literature search was conducted in Google Scholar and Scopus. Relevant studies were reviewed to answer the following questions:

- What are the key competencies students of SUD should acquire to make them capable of addressing key challenges?

- How best to teach SUD in a manner that crosses both disciplinary boundaries, as well as the boundaries between the HEI and the wider society? What are the key challenges in doing so? Further, what are the methods of teaching that can provide students with these key competencies?

- How has SUD has been taught in other HEIs, and what lessons can be learned from the various approaches?

We then conduct a case study on the development and implementation of a new bachelor's degree program, which has been developed using the theoretical basis described 
in the review. The purpose of the case study is not only to illustrate how theory is applied in practice, but also to highlight the context-specific nature of teaching and learning SUD, offering a situated account of a dynamic process through which theoretical ideas are translated into practice. Simultaneously, we add to existing academic discussion on SUD education by focusing on a less-studied geographical context and education level (bachelor's program). Our methods take inspiration from previous educational research with an ethnographic case study approach (e.g., $[15,16])$. This approach entails being immersed in natural environment of the research area and using an insider position to generate and analyze data. Our knowledge emerges both from previous literature and our own position as the developers and teachers of the bachelor's degree program. Data sources and methods include classroom observations, "field notes" by the lecturers, reflective discussions and exercises with SUD students assisted by the online mind map tool Flinga, and analysis of student learning diaries. When analyzing the data, we performed cross-checks to identify consistent themes and to resolve ambiguities that arose during some of the discussions. The combination of review and case study provides a useful way to obtain a comprehensive view of the complex phenomenon we are examining and provides answers to our research questions.

\section{Review of Current Practices in SUD Education}

\subsection{Contextual Challenges for SUD Education in HEIs}

There is a critical need for the knowledge, innovation, and skills to address significant challenges in sustainable development. HEIs have an important role to play in driving sustainable change - through the provision of education, skills, and research-and as such, universities globally have positioned themselves as critical actors in achieving sustainable development and the SDGs. In Finland this year, universities agreed on a number of theses intended to move sustainable development and responsibility "from words to actions".

However, teaching of sustainability poses a multitude of challenges to HEIs, as sustainability problems are inherently multidisciplinary, complex, and require a broad understanding of issues. Wiek et al. [17] claim that instead of focusing on isolated events, it is important to gain deep understanding of "sustainability problem constellations" in order to deal with the root causes of these events. This way of thinking directs attention to complex and dynamic processes that underlie individual, easily perceptible problems. These processes take place and interact across multiple scales and are dependent upon people's beliefs, habits, motives, and practices.

In addition, HEIs also face the challenge of needing to evolve to meet societal needs [18]. There is a need to change the ways that HEIs function and interact with wider society [19], including government and industry, in order to help develop the solutions to key environmental, social, and economic sustainability problems. Furthermore, HEI administrative structures are typically organized around rigid disciplinary frameworks, and integrating a broader, interdisciplinary subject such as sustainability into such a framework is challenging.

\subsection{Key Competencies in SUD}

Traditional teaching in HEIs has focused on knowledge specialization, reductionist thinking, and education within disciplinary silos [20]. However, there is a need to educate a new generation of professionals capable of analyzing and dealing with complex problems in sustainable development, and a narrow focus on knowledge acquisition limits the ability of graduates to gain a holistic, integrated understanding of the issues. In response, researchers have defined key competencies needed to develop a broad understanding of sustainability and solve real-life sustainability problems. Rather than focusing on cognitive learning, competencies focus on developing skills for solving diverse sets of problems, including effective communication, teamwork, and methododological competencies. The most widely used set of competencies for sustainable development is perhaps that of UNESCO [21] (Table 1), which is based Wiek et al.'s [22] synthesizing of key competencies 
in sustainability, and Rieckmann's [23] research on the key competencies that should be fostered through university teaching and learning:

Table 1. Key competencies for sustainability according to UNESCO [21].

\begin{tabular}{|c|c|}
\hline Competency & UNESCO Definition \\
\hline Systems thinking competency & $\begin{array}{l}\text { The abilities to recognize and understand relationships; } \\
\text { to analyze complex systems; to think of how systems are } \\
\text { embedded within different domains and different scales; } \\
\text { and to deal with uncertainty. }\end{array}$ \\
\hline Anticipatory competency & $\begin{array}{l}\text { The abilities to understand and evaluate multiple } \\
\text { futures-possible, probable, and desirable; to create } \\
\text { one's own visions for the future; to apply the } \\
\text { precautionary principle; to assess the consequences of } \\
\text { actions; and to deal with risks and changes. }\end{array}$ \\
\hline Normative competency & $\begin{array}{l}\text { The abilities to understand and reflect on the norms and } \\
\text { values that underlie one's actions; and to negotiate } \\
\text { sustainability values, principles, goals, and targets, in a } \\
\text { context of conflicts of interests and trade-offs, uncertain } \\
\text { knowledge, and contradictions. }\end{array}$ \\
\hline Strategic competency & $\begin{array}{l}\text { The abilities to collectively develop and implement } \\
\text { innovative actions that further sustainability at the local } \\
\text { level and further afield. }\end{array}$ \\
\hline Collaboration competency & $\begin{array}{l}\text { The abilities to learn from others; to understand and } \\
\text { respect the needs, perspectives, and actions of others } \\
\text { (empathy); to understand, relate to and be sensitive to } \\
\text { others (empathic leadership); to deal with conflicts in a } \\
\text { group; and to facilitate collaborative and participatory } \\
\text { problem solving. }\end{array}$ \\
\hline Critical thinking competency & $\begin{array}{l}\text { The ability to question norms, practices, and opinions; to } \\
\text { reflect on own one's values, perceptions, and actions; } \\
\text { and to take a position in the sustainability discourse. }\end{array}$ \\
\hline Self-awareness competency & $\begin{array}{l}\text { The ability to reflect on one's own role in the local } \\
\text { community and (global) society; to continually evaluate } \\
\text { and further motivate one's actions; and to deal with } \\
\text { one's feelings and desires. }\end{array}$ \\
\hline $\begin{array}{l}\text { Integrated problem-solving } \\
\text { competency }\end{array}$ & $\begin{array}{l}\text { The overarching ability to apply different } \\
\text { problem-solving frameworks to complex sustainability } \\
\text { problems and develop viable, inclusive, and equitable } \\
\text { solution options that promote sustainable development, } \\
\text { integrating the abovementioned competences. }\end{array}$ \\
\hline
\end{tabular}

"Key competencies represent cross-cutting competencies that are necessary for all learners of all ages worldwide (developed at different age-appropriate levels). Key competencies can be understood as transversal, multifunctional and contextindependent." [21]

All eight UNESCO competencies are highly necessary to tackle problems-wicked or otherwise-in sustainable development. In addition, all students need to be taught methodological competences like traditional project management techniques, planning and decision-making methods [24], skills to work across national, geographical, and cultural boundaries [25], and generic working life skills required for their future careers [26], as well as specialist skills and competencies related to their field of study. For example, technology graduates should have strong analytical and computer literacy skills. In social sciences, basic methodological, reading, writing and presentation skills are essential to understanding social scientific concepts and theories, as well as their relevance in making sense of everyday life [24]. These skills support the development of effective citizenship, 
enabling graduates to navigate in a politically polarized social climate and transform existing soci(et)al structures and patterns of behavior, including, inter alia, sexism, racism, and colonialism [25].

\subsection{Key Themes in SUD Education}

SUD is a problem- and solution-oriented field that operates in a complex environment of various communities of knowledge, non-academic stakeholders, and citizens. SUD education is not only about learning and producing knowledge, but also about goals, norms and visions of transition and transformation [27]. Therefore, we describe three interlinked themes that are vital in SUD education: transdisciplinary, reflective thinking and transformative learning. All these approaches demand the capability to think of problems, solutions, and their framing from multiple perspectives in various contexts.

\subsubsection{Interdisciplinarity and Transdisciplinarity}

Successful development of sustainable solutions in urban areas requires integrating knowledge and skills from multiple perspectives, and so a common theme for all competencies is the ability to think across disciplinary and institutional boundaries. The concepts of interdisciplinarity and transdisciplinarity are often referred to in ESD literature. Interdisciplinary education aims to teach students subjects from multiple perspectives, developing students' abilities to synthesize knowledge from different disciplines, change perspectives, and cope with complexity [28]. Transdisciplinary education extends this further, entailing solution-oriented collaboration between academics and non-academic actors $[20,27,29]$ and bringing the world outside of the HEI into student education [20]. Lang et al. [27] define transdisciplinarity in broad terms as follows:

"Transdisciplinarity is a reflexive, integrative, method-driven scientific principle aiming at the solution or transition of societal problems and concurrently of related scientific problems by differentiating and integrating knowledge from various scientific and societal bodies of knowledge."

As there is no single discipline that would cover the various aspects of SUD, interdisciplinary and transdisciplinary approaches—rather than monodisciplinary—are important (see, e.g., [30-32]). As a result, inter-/transdisciplinary education and research have started to become more commonplace although the monodisciplinary tradition still dominates HEI teaching practices. Indeed, a number of studies have discussed the importance of HEI teaching of sustainability aiming for transdisciplinary problem-based learning instead of the accumulation of discipline-based knowledge [33], and evidence suggests that it can improve course outcomes [34].

\subsubsection{Reflective Thinking}

Reflective or critical thinking refers to evaluating one's own thinking patterns whilst trying to solve problems in order to learn how to be able to think better in such situations $[35,36]$. It is an ability to think critically about practices, opinions, and norms, but also a capacity to reflect on your own values, perceptions, and actions [37] and understand external views. Pragmatist philosopher John Dewey defined reflective thinking:

"Active, persistent and careful consideration of any belief or supposed form of

knowledge in the light of the grounds that support it, and the further conclusions to which it tends, constitutes reflective thinking." [38]

Reflective thinking is hard to reduce to the definable learning outcomes traditionally used by HEIs. As Rodgers [39] has pointed out reflective thinking is not end itself, but rather a tool to transform an experience into meaning filled theory that is grounded in practice, informed by existing theory, and serves a bigger purpose of making society better. It is an iterative, progressive process from experience to theory and from theory to experience, with a similar form to scientific inquiry. While reflective thinking is central to HEI education, few educators actively teach students how to think critically. 


\subsubsection{Transformative Learning}

The key challenges of the Anthropocene demand transformative changes to society. In the field of sustainable development one faces uncertainty, poorly defined circumstances, and conflicting interests and realities. Still, these unknowns of the future need to be coped with a creative transformative commitment, rather than inaction [40].

Transformative or "experiential learning", as UNESCO [41] terms it, aims to challenge the core assumptions and values that teachers, students and as society hold. The teaching of SUD in HEIs should be transformative [35,42], focusing on the topics that are needed the most for societal transformation [43]. It shifts attention from the teacher to the student and emphasizes immediate experiences and close interaction with local communities [44]. Experiential learning can be further divided to several distinct—and partly overlappingapproaches. Some of these emphasize students' contribution to meeting the needs of local communities (e.g., service learning), while others focus on bridging scientific knowledge and practice by developing evidence-based solutions to real-life problems (e.g., problembased learning and solution-oriented learning), and still others focus on empowering students to acknowledge their capacity to make a difference (e.g., participatory action learning) [33,45-47]. Practical forms of learning and teaching associated with these approaches include project-based courses, studios, and workshops. The common denominator in these approaches is that they put significant emphasis on "how" to teach instead of focusing on "what" questions or the accumulation of knowledge related to SUD [19].

These forms of learning and teaching can be supported by teaching strategies that foster open-mindedness and open-ended trajectories, enabling and encouraging both teachers and students to confront hegemonic or conventional ideas, think about alternatives, and acknowledge different or opposing positions as well as underlying value. For example, interdisciplinary team-teaching brings together teachers from multiple faculties, schools, or disciplines to collaborate in planning and delivering courses [48]. This practice may be beneficial, not only because it encourages teachers to seek integration of different approaches and viewpoints, but also because it breaks existing boundaries. As Brewer [49] has noted, "the world has problems, but universities have departments". Thus, challenging or changing the institutional context in which knowledge is being (re)produced may ultimately enable universities to flexibly and effectively respond to the real-world sustainability problems.

\subsection{Teaching of SUD in Practice}

The above perspectives on competencies, teaching, and learning aim to equip students with the knowledge and skills to go beyond traditional empirical understanding ("what" and "why" questions) to knowledge synthesis, normative questions, and ethical analysis ("how and "should" questions).

Urban areas are at the center of many of the key sustainability challenges and are where the complexity of these challenges becomes manifest. As such, cities are prime examples of the multifaceted nature of sustainability challenges, which do not neatly follow the disciplinary boundaries of traditional HEI departments (see [49]). Instead, they call for various forms of collaboration that extend beyond existing institutional structures. Therefore, urban issues are often the focus in ESD curricula [45-47]. Urban areas offer abundant real-world learning settings where students can obtain first-hand observations and experiences of sustainability challenges, combine scientific knowledge with local knowledge, and engage in collaboration and co-creation of solutions with stakeholders and experts from various fields. These settings encourage active, student-centered learning, critical, inter- and transdisciplinary thinking and flexible application of different problemsolving frameworks, which are integral to acquiring key sustainability competencies and contributing to sustainability-oriented societal transformations $[35,46]$.

As global interest in sustainable development has increased, so have the number of higher education institutions offering degree programs on SUD [28,50-53]. However, often, the teaching of sustainability is integrated into existing curricula without a suitable 
pedagogical framework based on ESD [19,54], and many existing programs-for example in urban studies and urban planning - are facing the challenge of embedding sustainability in their teaching [55]. While there is general agreement of the value of inter- and transdisciplinarity in addressing sustainability problems, integrating sustainability into new or existing courses and programs can be challenging and there can be multiple barriers [56]. For example, challenges remain as to how collaboration between disciplines can and should be fostered in practice. Coordinating teaching between different schools and disciplines while fostering interaction with the wider society entails balancing commitments to research, service, and teaching in various study programs, overcoming administrative and institutional challenges, and negotiating working definitions of "sustainability" and ways of assessing of student work [48,57].

Developing transdisciplinary curricula in practice is not without its significant challenges [58]. Teachers in HEIs have typically not been educated in an inter- or transdisciplinary manner themselves and lack the training to use such approaches in their teaching $[59,60]$. It requires close collaboration between academics from different disciplines, designing course learning objectives, curricula, lectures, and workshops. It also requires that academics have the time to learn about sustainability issues within their own fields, as well as an appreciation for the perspectives and knowledge of their academic collaborators. However, without embedded inter- or transdisciplinary approaches, sustainability is taught within disciplinary silos without broader perspectives.

In response to this, many institutions are opting to develop new interdisciplinary programs in SUD (e.g., [28,51-53]), while there are fewer but increasing numbers of transdisciplinary courses (e.g., [61]). This trend is also apparent in the field of urban studies, which has witnessed the emergence of new master's and bachelor's degree programs. So far, research on inter- and transdisciplinary learning and teaching in the urban context has mostly focused on individual university courses (e.g., $[45,46,48,62])$ or their institutional settings [19] instead of entirely new study programs in SUD. The majority of existing interand transdisciplinary SUD degree programs are at postgraduate level, and there are a limited number of undergraduate degree programs on sustainable urban development that can provide students with different perspectives on sustainable development prior to establishing their disciplinary expertise.

\section{Case Study-SUD at Tampere University}

The above review highlights the critical need for transdisciplinary in sustainability teaching at HEIs, and that- to be successful-transdisciplinarity needs to be embedded in the core of the teaching curricula. In addition, there are core skills that future sustainability professionals must have, and different pedagogical approaches to help students develop these skills. There are therefore opportunities to offer undergraduate degree programs on SUD that include transdisciplinarity and effective pedagogical practices at the very core of the program.

In response, Tampere University has developed a new SUD Bachelor's Degree Program, jointly delivered by the faculties of Social Sciences, Administrative Sciences, and the Built Environment. This program aims to provide students with an inter- and transdisciplinary education on sustainable urban development, with the opportunity to study three streams: administrative sciences, social sciences, and technology. While each stream has courses specific to the disciplines, all students participate in common courses on sustainable development. It is an international program, taught in English to local and overseas students, and with both a local and global perspective.

\subsection{Program Development}

The development of the SUD program began in 2018 when two universities in the city of Tampere-University of Tampere and Tampere University of Technology-were preparing a merger. There were many drivers for the merger but an important one was the belief that the new structure would provide better opportunities for interdisciplinary 
research and education. The merger was completed in 2019, and the merged university was named Tampere University. In order to support the merger process and facilitate interdisciplinary collaboration, pilot projects were identified and given financial resources. SUD education was selected as a pilot project because of the societal relevance, and because there was an existing research collaboration between the scholars of the merged universities.

The planning of the SUD program took two and a half years. During the first year, several seminar events were held, during which the theme and the idea of the program was discussed and developed by urban development practitioners and scholars. Based on these seminars, it was decided that the new program would be at bachelors' level, delivered by three collaborating faculties. The faculties and disciplines were chosen based on relevance to the theme, the existing research connections, and participants' engagement in planning.

The first year of program development was challenging because the new interdisciplinary and multi-faculty program did not fit existing institutional structures, and it was not clear how it would be connected to existing programs or their resources. It took time to develop a model that was acceptable to key stakeholders. A key decision was to develop an international English language bachelor's program-novel in contrast to the existing bachelor's programs at the participating faculties that were all in Finnish.

The second year of planning involved detailed discussions of the learning objectives and content, mainly by a team representing the three participating faculties, but with several events for faculty members and stakeholders, e.g., representatives of the City of Tampere, to provide feedback and ideas. Substantial iterations were required to develop a curriculum that would cover both the common SUD learning objectives, discipline-specific postgraduate eligibility, and various administrative and other requirements from the three faculties. At the end of the second year, three lecturers were recruited to take over the final planning and launch. The first intake of students was admitted during Spring 2020, and teaching began in August 2020. Detailed planning is still being undertaken as the new courses are being developed and delivered.

\subsection{Theoretical Basis of the Tampere SUD Program}

The development of the program has been framed by current research, outlined in the review above. It is designed to overcome some of the limitations of current ESD teaching by:

- Developing students core competencies, as framed by UNESCO, as well as additional competencies in intercultural communication and languages, and disciplinespecific knowledge.

- Teaching sustainability at the undergraduate level, prior to the development of students' discipline identity and enabling them to learn transdisciplinary thinking at an early stage. This is in contrast to many of the current existing degree programs that are at master's level only.

- It is designed for interdisciplinary teaching of sustainability from the outset, rather than as an add-on to existing degree programs, and the structure allows students the opportunity to learn from different perspectives and interact with other students from different streams during workshops and projects throughout their studies.

- It provides opportunities for engagement with stakeholders outside of the university during transdisciplinary project-based courses.

The degree structure and curriculum can be seen in Figure 1. The degree program has learning outcomes for all students, as well as outcomes for specific streams. All students will graduate with a holistic understanding of the key concepts, interlinkages, actors, questions, conflicts, and solutions in the field of sustainable urban development globally, as well as the core discipline-specific skills that are required by employers or to continue on to masters level. Those in the technology stream will also gain a foundational knowledge of mathematics, physical sciences, and computer science as they relate to the urban environment. Students in administrative sciences will be able to understand the administrative, political, and economic phenomena in cities, as well as the key concepts 
in administrative sciences. Finally, students in the social science stream will understand the key theories, concepts and methods in social sciences, and the societal significance of social research. The curriculum has been designed with core courses on sustainability throughout the degree, bringing together the students in the separate streams for these common interdisciplinary and/or transdisciplinary courses in each year of study.

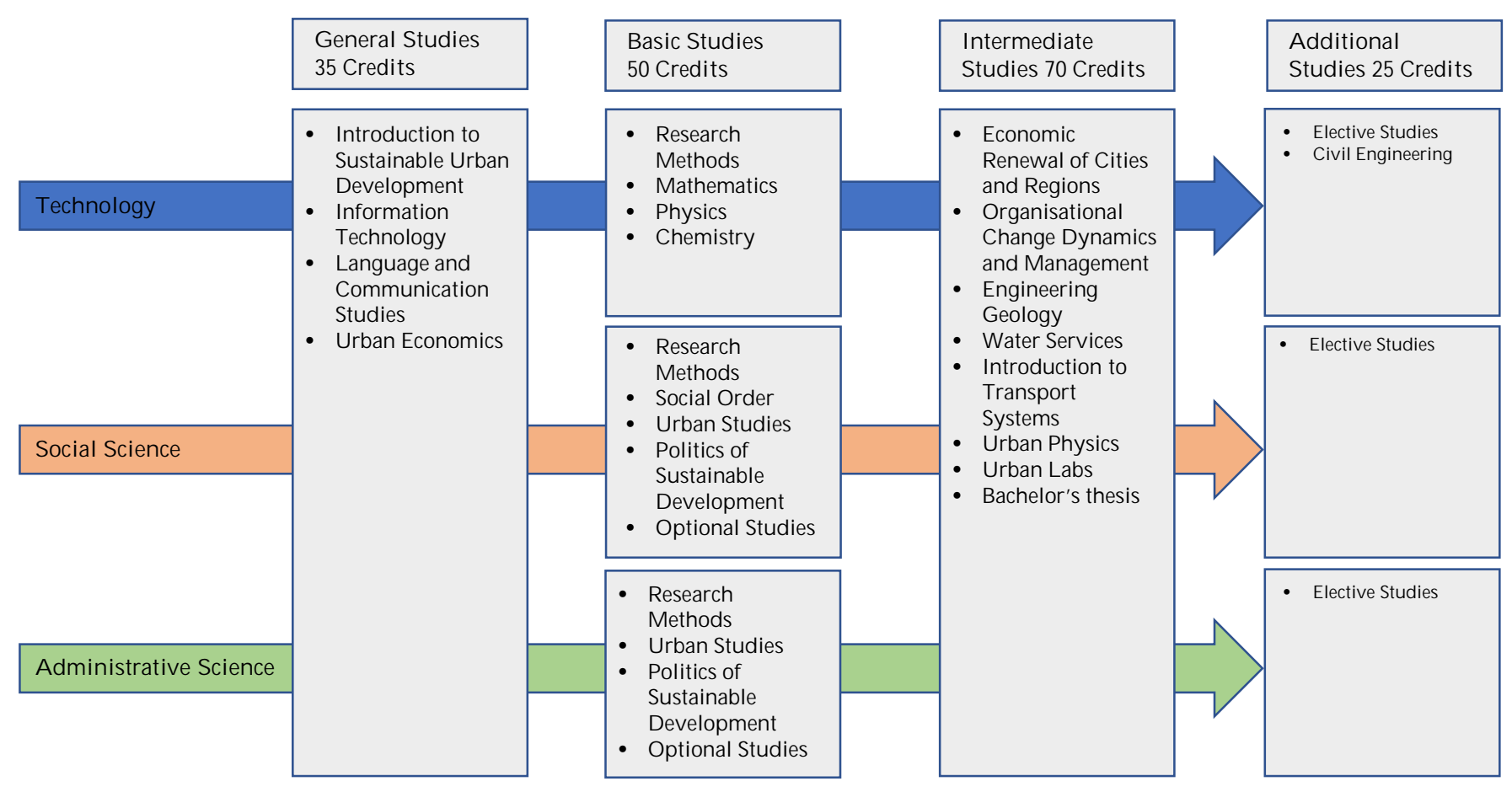

Figure 1. Degree structure and curriculum.

The degree program has resulted in the development of several new courses, common to all SUD students. These courses are intended to integrate across the degree curriculum, unifying concepts and providing interdisciplinary or transdisciplinary perspectives on common subject matters. This enables students to make connections and give broader perspectives on the issues they have been taught in more traditional subject-specific courses. Common courses have been developed and are delivered by three lecturers, one from each faculty, using team-based teaching to deliver integrated learning; these lecturers are provided the resources and support from the university to do so.

While the common integrating courses are intended to provide an interdisciplinary foundation, a unique element of the SUD degree program is the transdisciplinary teaching in the two Urban Lab courses. These courses will enable students to engage in real-life urban development projects in collaboration with public organizations such as the City of Tampere, or with commercial organizations. Currently, urban lab projects done in collaboration with Tampere city will make use of a future city district-Hiedanranta-as a real-life laboratory. Hiedanranta is being developed as a testbed for innovative projects related to smart and sustainable housing, energy, transportation, and business, providing ample opportunities for students to engage with actors outside of the university on realworld projects. These project-based courses also allow for students to collaborate between streams to get continued experience working with different perspectives.

\subsection{Reflections on Tampere SUD Program}

Here we present an analysis of the SUD program, mapping elements of the degree to the reviewed perspectives. The SUD degree aims to enable students to develop key UNESCO competencies so that they are capable of solving problems with professionals from different backgrounds. In particular, the degree focuses on systems thinking, strate- 
gic, collaboration, and integrated problem-solving competencies, as well as intercultural communication. These competencies are strengthened in the common SUD courses, where students from different streams are asked to work together in group projects, workshops, or in reading groups. The project work and teaching methods are designed to strengthen the core competencies, and include problem-based learning, game-based learning, and team-based learning. The methods of implementing core competencies and inter and transdisciplinarity into the degree program is summarized in Table 2.

By including common courses for all SUD students throughout the degree program, it is ensured that students are regularly engaged in interdisciplinary studies, and mixed groupwork ensures that multiple perspectives are included in each group. This helps strengthen and facilitate interdisciplinary collaboration. In addition, the Urban Lab courses provide the opportunity to work on projects outside of the university, promoting transdisciplinary education. By taking a team-based teaching approach, we are able to approach important topics in sustainability from multiple angles within the same lecture. A key means of assessing the common SUD courses are student learning diaries, which prioritize their understanding of concepts across multiple perspectives, and their personal reflections. From this, lecturers are able to gauge students reflective learning and critical thinking. The reflections also entail important feedback, which helps both students and teachers to adjust their behavior and practices to meet the objectives of the program as effectively as possible.

\subsubsection{Analysis of the Program from the Student Perspective}

The first cohort of 18 SUD students began their studies in Autumn 2020. The students come from diverse backgrounds, including six different nationalities, and with both recent high school graduates and more mature students. Initial feedback collected form the students indicate a mixture of different long-term ambitions, with students hoping for careers in, for example, research and development or governmental organizations, while more than half have no clear career ambitions just yet. A key attraction of the program for the students was the interdisciplinary teaching, providing the students the opportunity to develop their interests in a subject area that they are passionate about.

To tease out students' understanding about transdisciplinarity, a reading group session was organized where the focus was on an article, "Imagining the post-fossil city: why is it so difficult to think of new possible worlds? [43]." One question that was reflected on in breakout rooms (with mixed participants from different streams) and together was "Keys to a post-fossil city: What perspectives or competencies need to be combined to create a walkable city?" in order to understand how students envision transdisciplinary approaches in a practical context. The answers varied from a need for a comprehensive understanding or a vision of sustainable urban development; understanding intended and unintended policy outcomes; behavioral patterns of humans; the art of nudging; understanding urban transportation systems; or the dimensions of urban green as social, ecological, and technical. The benefit of the discussion was that it demonstrated the multiple disciplinary angles needed when considering SUD.

Reflective thinking was encouraged in several ways during our first two courses. Students analyzed issues in learning diaries, where they reflected the contents of each lecture in relation to their own experiences. One of the issues of reflection was a debate exercise facilitated using game-based learning. One student wrote that, "I think that fully listening what another person is has to say can allow questions to arise, like why this person in thinking this way. Are there factors like age, culture or the media, that could be shaping their views? This exercise also showed me that other people's viewpoints are not wrong and perhaps I could examine my own." This quote illustrates the possibilities of transdisciplinarity, as the co-existence of three the disciplines in SUD demand a continuous reflection of disciplinary frames. 
Table 2. Analysis of the SUD program.

\begin{tabular}{|c|c|c|}
\hline & & Integration into Degree Program \\
\hline \multirow{6}{*}{ Core Competencies } & Systems Thinking & $\begin{array}{l}\text { Systems thinking workshops in the common courses are used to draw } \\
\text { connections between different elements of urban systems for hypothetical } \\
\text { development scenarios and identify unintended consequences. }\end{array}$ \\
\hline & Strategic & $\begin{array}{l}\text { During the Urban Lab courses, students will be expected to collaborate and } \\
\text { develop plans to address sustainability issues of their choosing. }\end{array}$ \\
\hline & Collaboration & $\begin{array}{l}\text { Students from different discipline streams are tasked with collaborating within } \\
\text { groups in workshops and projects in all SUD common courses. } \\
\text { In the Introduction to Social Scientific Research and Academic Writing course, } \\
\text { the Teams-Based Learning tools are used to teach teams of students about how } \\
\text { to read and understand academic articles. }\end{array}$ \\
\hline & Critical thinking & $\begin{array}{l}\text { Game-based learning is used to encourage students discuss and debate topics } \\
\text { from points of view that they personally may not share. } \\
\text { In various courses, students are assigned to reading groups, mixed by degree } \\
\text { stream, and asked to read and reflect on a selection of assigned newspapers } \\
\text { and journal articles and books. } \\
\text { In all social science teaching, students are enabled and encouraged to identify } \\
\text { and question existing soci(et)al structures, norms, worldviews etc.Students use } \\
\text { methodological skills to analyze and interpret urban and societal phenomena. }\end{array}$ \\
\hline & $\begin{array}{l}\text { Integrated Problem } \\
\text { Solving }\end{array}$ & $\begin{array}{l}\text { During the Urban Lab courses, students are divided into groups, with each } \\
\text { group containing students from different streams. In collaboration with the } \\
\text { university lecturers and stakeholders from city government and local business, } \\
\text { they design their own research projects. This provides students with } \\
\text { opportunities for contextual learning and problem-based learning. }\end{array}$ \\
\hline & $\begin{array}{l}\text { Intercultural } \\
\text { Communication }\end{array}$ & $\begin{array}{l}\text { All students are required to study a foreign language. In addition, first year } \\
\text { students attend an intercultural communication course, during which local } \\
\text { and international students work together in groups to learn about } \\
\text { cross-cultural communication patterns. }\end{array}$ \\
\hline \multirow{3}{*}{ Disciplinarity } & Specific & $\begin{array}{l}\text { Students attend discipline-specific courses related to their study stream to } \\
\text { obtain relevant knowledge and skills. }\end{array}$ \\
\hline & Interdisciplinary & $\begin{array}{l}\text { A number of interdisciplinary courses are taught throughout the degree } \\
\text { program, which all students attend. These courses are taught by each SUD } \\
\text { lecturer using team-based teaching and are intended to draw together } \\
\text { discipline-specific perspectives on sustainable development. }\end{array}$ \\
\hline & Transdisciplinary & $\begin{array}{l}\text { Two Urban Lab courses require interdisciplinary collaboration between } \\
\text { students from different streams. A key part of the courses is the engagement } \\
\text { with organizations outside of the university on real-world problems using the } \\
\text { city as a "living lab". }\end{array}$ \\
\hline \multirow[b]{2}{*}{ Thinking } & Transformative & $\begin{array}{l}\text { The Urban Lab courses and some other courses as well are connected to } \\
\text { real-life SUD problems, which the students aim at addressing in collaboration } \\
\text { with groups external to the university. The purpose of these learning events is } \\
\text { to develop understanding on how to make positive changes happen. }\end{array}$ \\
\hline & Reflective & $\begin{array}{l}\text { We aim to promote reflective thinking in several ways. First, three streams } \\
\text { provide different perspectives automatically, second by engaging students into } \\
\text { discussion of possible scientific approaches and ways to construct an argument } \\
\text { through scientific books, journal articles and systematic writing practice and } \\
\text { third, adopting transformative learning. }\end{array}$ \\
\hline
\end{tabular}

To understand the views of students on how the degree could support their learning, we asked students, "How can you become an active agent in sustainable urban development?" and "How can university studies support you in this task?" and made an interactive Flinga mind map to record their responses. Some responses focused on skills such as "learning to make an argument in layman's terms" and "integration of technological solutions and understanding discourses and imageries". Other students focused on actions such 
as "participating in municipal politics", "sharing spaces [such as saunas or maker-spaces) and items and repairing them", "supporting public transportation", "getting to know real life actors in urban development and their relationships", and "participate in events available to youth". The answers to the second question were in line to our thinking about project-based courses, as students mentioned "Urban Labs" as a possibility to meet real life SUD actors and networking and gain "knowledge about resources, where to get information, what to read and follow", which we believe is best tackled through co-operation between the university and real-world development projects. Finally, there was also an understandable wish to get "knowledge about future career options". The answers reflect first, the broad field of SUD a demand for integrative understanding, and second, the fact that many students are coming straight from high school to the SUD program and their professional futures are still somewhat uncertain.

\subsubsection{Initial Reflections from SUD Lecturers}

While the program is relatively new, there have been a number of valuable lessons learned during its development. Course development and team-based teaching has required that the three lecturers from different faculties-with their own disciplinary backgrounds - have had to spend considerable time learning about sustainability issues of the other two disciplinary fields. This requires a significant time commitment, as well as a need to be open minded to different teaching traditions, perspectives on topics and understand the importance of these perspectives for sustainable development. For this reason, it has been advantageous to recruit new lecturers who are enthusiastic about interdisciplinary collaboration, and are aware of the working requirements prior to beginning, rather than expecting existing staff to take on the extra commitment. It has also required the commitment from the university administration to provide the lecturers with the time and support to engage in this "invisible" work.

The team-based teaching approach and emphasis on student interaction has required flexibility in teaching schedules, as students may show particular interest in an idea or perspective which means teaching takes longer and there is less time to cover other perspectives. The coronavirus situation in Finland in 2020 has meant that teaching began using hybrid in-person and online methods, enabling students who were not able to attend to learn remotely. This has, however, provided interesting opportunities to use the coronavirus as a topic to learn about key sustainability issues globally, such as global urban connectivity, density, behavior changes, emissions, biodiversity, and human encroachment into nature.

According to Keeley and Benton-Short [48], one of the challenges of interdisciplinary team-based teaching is that teachers from different fields do not necessarily agree on what should be included in a course or even what the definitions of key concepts are. While the lecturers have spent time in identifying the core content, team-teaching has nevertheless been an act of balancing between having a shared understanding of the content and goals of teaching and using heterogeneous views to engage students in exploring the complexity of inherently interdisciplinary issues. Heterogeneity of voices may be valuable in its own right, because, as Sennett [63] argues, it encourages ethical practice of communication based on outward-looking orientation, willingness to listen to others, and cooperation rather than confrontation. This kind of communication is needed when "coping with complex realities [of cities] in which finesse and skill replace naked pushiness".

The hybrid teaching - with students both present in class and online-presented a number of challenges. Lecturers used Flinga to do groupwork and create discussion with the whole group with those who were present and who were online. In addition, Mentimeter was used to rank and discuss the ideas and themes within topics with the students, and Kumu was used for mapping systems thinking discussions. Zoom breakout rooms were utilized for having smaller group discussions and game-based learning activities. These online tools worked well, especially in finding out how students were reflecting on SUD 
issues. However, the interaction with the students was harder to create than in face to face situation, and there was mixed success fostering engagement.

\section{Discussion and Conclusions}

The review of existing teaching of SUD describes the changing relationship between universities and wider society, and how ESD graduates need to have a set of core competencies that will enable them to drive sustainable change. It also discusses the importance of interdisciplinary and transdisciplinary teaching of SUD, and the critical need to students to experience critical reflection and transformative learning. However, as noted in the review, such teaching is difficult to integrate into existing degree programs, and many programs are focused on integrating sustainability into existing degree programs rather than in pedagogical frameworks developed for ESD. The Tampere SUD program has been developed in response to this need, incorporating interdisciplinary teaching and learning from the ground-up, with a pedagogical framework based on available information on best practice in ESD.

This paper promotes a new line of thinking in educating future professionals on sustainable development issues. It provides a description of the theoretical framework for ESD curricula to address SUD and subsequent development of the Tampere SUD program. It addresses one of the key challenges of sustainable development for HEI teaching at the moment: How to educate professionals able of addressing economic, environmental, and social aspects of sustainability in the living environments and global scales, and capable of developing viable, inclusive, and equitable solutions that promote sustainable development respectively?

Our paper contributes to ESD curricula by synthesizing extant literature on education and learning of SUD. It reviews competencies required to tackle wicked problems in SUD and different pedagogic practices to achieve these competences in an inter- and transdisciplinary teaching program. The synthesis provides a structured overview of relevant perspectives to be considered and approaches to be used in developing SUD education. It applies the synthesis of competences and pedagogical practices in SUD education to describe and analyze a new Tampere SUD Bachelor degree program, contributing a practical understanding of how to apply ESD curricula to educate future experts on sustainable urban development issues. The program aims to provide students with the holistic knowledge necessary to consider development problems from multiple perspectives in addition to providing them with discipline-specific fundamental skills.

Both the literature-based synthesis and the case study provide useful insights for scholars developing more nuanced understanding of SUD education and for HEI actors developing SUD education initiatives in practice. While the literature review revealed that most of the existing SUD education initiatives include individual SUD courses, add-on elements to existing programs and master's level programs, the Tampere SUD is an example of a bachelor level program constructed especially to equip future SUD professionals with the skills and transdisciplinary understanding to enact sustainable change in a global context. The planning of Tampere SUD program and first implementation provide an understanding of how SUD educational approaches can be applied in practice at university degree programs.

The Tampere SUD program is relatively new, and further research and evaluation is necessary to determine how students are achieving the program objectives for core competencies, interdisciplinary thinking, and transformative and critical thought. There will be opportunities to refine the degree program in coming years using student feedback and assessments of the achievements of competence objectives. All this will provide practical knowledge on how to restructure ESD curricula to support learning of sustainable urban development also in other HEIs and how research should be developed to support this process. 
Author Contributions: Conceptualization, A.L., J.R., P.J., and L.H.; writing-original draft preparation, J.T., S.J., and M.L.; writing-review and editing, J.T., S.J., M.L., A.L., J.R., and P.J.; funding acquisition, A.L., L.H., and P.J. All authors have read and agreed to the published version of the manuscript.

Funding: This research received no external funding.

Informed Consent Statement: Informed consent was obtained from students to quote their written text and share their reflections on the degree programme.

Data Availability Statement: Data is contained within the article.

Acknowledgments: The Tampere University SUD program has been developed during a lengthy process involving several people in addition to the authors of article. The authors want to acknowledge the valuable contribution of several faculty members, students, and external stakeholders at various stages of program development. The authors would also like to acknowledge the contributions of the SUD students in providing their reflections on SUD and the degree program.

Conflicts of Interest: The authors declare no conflict of interest.

\section{References}

1. Steffen, W.; Richardson, K.; Rockstrom, J.; Cornell, S.E.; Fetzer, I.; Bennett, E.M.; Biggs, R.; Carpenter, S.R.; de Vries, W.; de Wit, C.A.; et al. Planetary boundaries: Guiding human development on a changing planet. Science 2015, 347, 1259855. [CrossRef] [PubMed]

2. Dempsey, N.; Bramley, G.; Power, S.; Brown, C. The social dimension of sustainable development: Defining urban social sustainability. Sustain. Dev. 2011, 19, 289-300. [CrossRef]

3. Meuleman, L. Metagovernance for Sustainability: A Framework for Implementing the Sustainable Development Goals. Public Sect. Econ. 2019, 43, 109-113. [CrossRef]

4. Tàbara, J. Social learning to cope with global environmental change and unsustainability. In Routledge International Handbook of Social and Environmental Change; Lockie, S., Sonnenfeld, D., Fisher, D.R., Eds.; Routledge: New York, NY, USA, 2013.

5. United Nations. World Urbanization Prospects: The 2018 Revision; United Nations: New York, NY, USA, 2018.

6. Swilling, M.; Robinson, B.; Marvin, S.; Hodson, M.; Hajer, M. City-Level Decoupling: Urban Resource Flows and the Governance of Infrastructure Transitions. In A Report of the Working Group on Cities of the International Resource Panel; United Nations Environment Programme: Nairobi, Kenya, 2013.

7. Giles-Corti, B.; Vernez-Moudon, A.; Reis, R.; Turrell, G.; Dannenberg, A.L.; Badland, H.; Foster, S.; Lowe, M.; Sallis, J.F.; Stevenson, M.; et al. City planning and population health: A global challenge. Lancet 2016, 388, 2912-2924. [CrossRef]

8. Kleinert, S.; Horton, R. Urban design: An important future force for health and wellbeing. Lancet 2016, 388, 2848-2850. [CrossRef]

9. Watts, N.; Amann, M.; Arnell, N.; Ayeb-Karlsson, S.; Belesova, K.; Boykoff, M.; Byass, P.; Cai, W.; Campbell-Lendrum, D.; Capstick, S.; et al. The 2019 report of The Lancet Countdown on health and climate change: Ensuring that the health of a child born today is not defined by a changing climate. Lancet 2019, 394, 1836-1878. [CrossRef]

10. Grandin, J.; Haarstad, H.; Kjærås, K.; Bouzarovski, S. The politics of rapid urban transformation. Curr. Opin. Environ. Sustain. 2018, 31, 16-22. [CrossRef]

11. Yigitcanlar, T.; Teriman, S. Rethinking sustainable urban development: Towards an integrated planning and development process. Int. J. Environ. Sci. Technol. 2015, 12, 341-352. [CrossRef]

12. Mullally, G.; Byrne, E.; Sage, C. Disciplines, Perspectives and Conversations. In Transdisciplinary Perspectives on Transitions to Sustainability; Byrne, E., Mullally, G., Sage, C., Eds.; Routledge: London, UK, 2017.

13. Jahn, T. Theory of sustainability? Considerations on a basic understanding of "sustainability science". In Theories of Sustainable Development; Enders, J., Remig, M., Eds.; Routledge: London, UK, 2015.

14. Diefenbacher, H. Ten theses on a research agenda for sustainable development. In Theories of Sustainable Development; Enders, J., Remig, M., Eds.; Routledge: London, UK, 2015; pp. 188-194.

15. Kester, K. The contribution (or not) of UN higher education to peacebuilding: An ethnographic account. Glob. Soc. Educ. 2017, 15, 464-481. [CrossRef]

16. Craft, A.; Cremin, T.; Hay, P.; Clack, J. Creative primary schools: Developing and maintaining pedagogy for creativity. Ethnogr. Educ. 2014, 9, 16-34. [CrossRef]

17. Wiek, A.; Withycombe, L.; Redman, C.L. Key competencies in sustainability: A reference framework for academic program development. Sustain. Sci. 2011, 6, 203-218. [CrossRef]

18. Wowk, K.; McKinney, L.; Muller-Karger, L.; Moll, R.; Avery, S.; Escobar-Briones, E.; Yoskowitz, D.; McLaughlin, R. Evolving academic culture to meet societal needs. Palgrave Commun. 2017, 3. [CrossRef]

19. Biberhofer, P.; Rammel, C. Transdisciplinary learning and teaching as answers to urban sustainability challenges. Int. J. Sustain. High. Educ. 2017, 18, 63-83. [CrossRef] 
20. Remington-Doucette, S.M.; Connell, K.Y.H.; Armstrong, C.M.; Musgrove, S.L. Assessing sustainability education in a transdisciplinary undergraduate course focused on real-world problem solving: A case for disciplinary grounding. Int. J. Sustain. High. Educ. 2013, 14, 404-433. [CrossRef]

21. Rieckmann, M. Education for Sustainable Development Goals: Learning Objectives; UNESCO: London, UK, 2017.

22. Wiek, A.; Withycombe, L.; Redman, C.; Mills, S.B.; Banas, S. Moving Forward on Competence in Sustainability Research and Problem Solving. Environment 2011, 53, 3-13. [CrossRef]

23. Rieckmann, M. Future-oriented higher education: Which key competencies should be fostered through university teaching and learning? Futures 2012, 44, 127-135. [CrossRef]

24. Steiner, G.; Posch, A. Higher education for sustainability by means of transdisciplinary case studies: An innovative approach for solving complex, real-world problems. J. Clean. Prod. 2006, 14, 877-890. [CrossRef]

25. Wiek, A.; Bernstein, M.J.; Laubichler, M.; Caniglia, G.; Minteer, B.; Lang, D.J. A Global Classroom for International Sustainability Education. Creat. Educ. 2013, 4, 19-28. [CrossRef]

26. Karvinen, M.; Vehmaa, A.; Keskinen, M. Muuttuvien työelämätaitojen sisällyttäminen tekniikan alan koulutukseen: Tapaustutkimus Aalto-yliopiston vesi- ja ympäristötekniikan maisteriohjelmasta. Yliopistopedagogiikka 2019, 2019, $20-41$.

27. Lang, D.J.; Wiek, A.; Bergmann, M.; Stauffacher, M.; Martens, P.; Moll, P.; Swilling, M.; Thomas, C.J. Transdisciplinary research in sustainability science: Practice, principles, and challenges. Sustain. Sci. 2012, 7, 25-43. [CrossRef]

28. Spelt, E.J.H.; Biemans, H.J.A.; Tobi, H.; Luning, P.A.; Mulder, M. Teaching and learning in interdisciplinary higher education: A systematic review. Educ. Psychol. Rev. 2009, 21, 365-378. [CrossRef]

29. Kates, R.W.; Clark, W.C.; Corell, R.; Hall, J.M.; Jaeger, C.C.; Lowe, I.; McCarthy, J.J.; Schellnhuber, H.J.; Bolin, B.; Dickson, N.M.; et al. Environment and development: Sustainability science. Science 2001, 292, 641-642. [CrossRef] [PubMed]

30. Brint, S.G.; Turk-Bicakci, L.; Proctor, K.; Murphy, S.P. Expanding the social frame of knowledge: Interdisciplinary, degree-granting fields in american colleges and universities, 1975-2000. Rev. High. Educ. 2009, 32, 155-183. [CrossRef]

31. Klein, J.T.; Newell, W.H. Advancing Interdisciplinary Studies. In Handbook of the Undergraduate Curriculum: A Comprehensive Guide to Purposes, Structures, Practices, and Change; Gaff, J., Ratcliff, J., Eds.; Jossey-Bass: San Francisco, CA, USA, 1997 ; pp. $393-415$.

32. Miller, M.A.; Mccartan, A.-M. At the Crossings: Making the Case for New Interdisciplinary Programs. Chang. Mag. Higher Learn. 1990, 22, 28-35. [CrossRef]

33. Thomas, I. Critical Thinking, Transformative Learning, Sustainable Education, and Problem-Based Learning in Universities. J. Transform. Educ. 2009, 7, 245-264. [CrossRef]

34. Greenhalgh-Spencer, H.; Frias, K.; Ertas, A. Transdisciplinary content pedagogy in undergraduate engineering education: Being pulled up short. In Transdisciplinary Higher Education: A Theoretical Basis Revealed in Practice; Springer International Publishing: New York, NY, USA, 2017; pp. 73-89, ISBN 9783319561851.

35. Howlett, C.; Ferreira, J.A.; Blomfield, J. Teaching sustainable development in higher education: Building critical, reflective thinkers through an interdisciplinary approach. Int. J. Sustain. High. Educ. 2016, 17, 305-321. [CrossRef]

36. Paul, R. Critical thinking in every domain and belief. In Proceedings of the 27th Annual International Conference on Critical Thinking, Berkeley, CA, USA, 23-26 July 2007.

37. Lozano, R.; Merrill, M.; Sammalisto, K.; Ceulemans, K.; Lozano, F. Connecting Competences and Pedagogical Approaches for Sustainable Development in Higher Education: A Literature Review and Framework Proposal. Sustainability 2017,9 , 1889. [CrossRef]

38. Dewey, J. How We Think; D. C. Heath and Company: Boston, MA, USA, 1910.

39. Rodgers, C. Defining Reflection: Another Look at John Dewey and Reflective Thinking. Teach. Coll. Rec. 2002, 104, 842-866. [CrossRef]

40. Wals, A.E.J. Between knowing what is right and knowing that is it wrong to tell others what is right: On relativism, uncertainty and democracy in environmental and sustainability education. Environ. Educ. Res. 2010, 16, 143-151. [CrossRef]

41. UNESCO. Teaching and Learning for a Sustainable Future: A Multimedia Teacher Education Programme; UNESCO: Paris, France, 2002.

42. Cranton, P. Understanding and Promoting Transformative Learning, 2nd ed.; Jossey-Bass: San Francisco, CA, USA, 2006.

43. Hajer, M.; Versteeg, W. Imagining the post-fossil city: Why is it so difficult to think of new possible worlds? Territ. Polit. Gov. 2019, 7, 122-134. [CrossRef]

44. Korobar, V.P.; Siljanoska, J. Challenges of teaching sustainable urbanism. Energy Build. 2016, 115, 121-130. [CrossRef]

45. Li, N.; Chan, D.; Mao, Q.; Hsu, K.; Fu, Z. Urban sustainability education: Challenges and pedagogical experiments. Habitat Int. 2018, 71, 70-80. [CrossRef]

46. Wiek, A.; Kay, B. Learning while transforming: Solution-oriented learning for urban sustainability in Phoenix, Arizona. Curr. Opin. Environ. Sustain. 2015, 16, 29-36. [CrossRef]

47. Molnar, C.; Ritz, T.; Heller, B.; Solecki, W. Using Higher Education-Community Partnerships to Promote Urban Sustainability. Environ. Sci. Policy Sustain. Dev. 2010, 53, 18-28. [CrossRef]

48. Keeley, M.; Benton-Short, L. Holding complexity: Lessons from team-teaching an interdisciplinary collegiate course on urban sustainability. Soc. Sci. 2020, 9, 76. [CrossRef]

49. Brewer, G.D. The Challenges of Interdisciplinarity. Policy Sci. 1999, 32, 327-337. [CrossRef]

50. Bursztyn, M.; Drummond, J. Sustainability science and the university: Pitfalls and bridges to interdisciplinarity. Environ. Educ. Res. 2014, 20, 313-332. [CrossRef] 
51. Brodin, E.M.; Avery, H. Cross-Disciplinary Collaboration and Scholarly Independence in Multidisciplinary Learning Environments at Doctoral Level and Beyond. Minerva 2020, 58, 409-433. [CrossRef]

52. Foley, G. Reflections on interdisciplinarity and teaching chemical engineering on an interdisciplinary degree programme in biotechnology. Educ. Chem. Eng. 2016, 14, 35-42. [CrossRef]

53. Lindvig, K.; Lyall, C.; Meagher, L.R. Creating interdisciplinary education within monodisciplinary structures: The art of managing interstitiality. Stud. High. Educ. 2019, 44, 347-360. [CrossRef]

54. Lambrechts, W.; Mulà, I.; Ceulemans, K.; Molderez, I.; Gaeremynck, V. The integration of competences for sustainable development in higher education: An analysis of bachelor programs in management. J. Clean. Prod. 2013, 48, 65-73. [CrossRef]

55. Bina, O.; Balula, L.; Varanda, M.; Fokdal, J. Urban studies and the challenge of embedding sustainability: A review of international master programmes. J. Clean. Prod. 2016, 137, 330-346. [CrossRef]

56. Argento, D.; Einarson, D.; Mårtensson, L.; Persson, C.; Wendin, K.; Westergren, A. Integrating sustainability in higher education: A Swedish case. Int. J. Sustain. High. Educ. 2020, 21, 1131-1150. [CrossRef]

57. Barth, M. Implementing Sustainability in Higher Education: Learning in an Age of Transformation; Routledge: London, UK, 2014.

58. Balsiger, J. Transdisciplinarity in the class room? Simulating the co-production of sustainability knowledge. Futures 2015, 65, 185-194. [CrossRef]

59. Filho, W.L.; Manolas, E.; Pace, P. The future we want key issues on sustainable development in higher education after Rio and the UN decade of education for sustainable development. Int. J. Sustain. High. Educ. 2015, 16, 112-129. [CrossRef]

60. Ceulemans, K.; De Prins, M.; Cappuyns, V.; De Coninck, W. Integration of sustainable development in higher education's curricula of applied economics: Large-scale assessments, integration strategies and barriers. J. Manag. Organ. 2011, 17, 621-640. [CrossRef]

61. Neuhauser, L.; Pohl, C. Integrating transdisciplinarity and translational concepts and methods into graduate education. In Transdisciplinary Professional Learning and Practice; Springer: Cham, Switzerland, 2015; pp. 99-120.

62. Christiansen, L.; Fischer, N. Teaching Urban Sociology and Urban Sustainability on Two Feet, Two Wheels, and in Three Cities. Teach. Sociol. 2010, 38, 301-313. [CrossRef]

63. Sennet, R. Building and Dwelling: Ethics for the City; Penguin Books: London, UK, 2019. 